there. He soon began to take an active part in local affairs and to enjoy his garden and the new duties and obligations which life in a small rural com. munity involved. But further illness soon supervened, and his last years were, in the main, a brave struggle against persistent and painful ill-health, in spite of which he managed to accomplish much valuable work in the way of revising and preparing new editions of his books.

Imms married in 1913 Miss Georgina Mary French, of County Tyrone, who, with their two daughters, survives him. W. H. THORPE

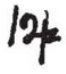

\section{Mr. W. A. Knight}

Mr. WirLiam A. KNIGHT, the first headmaster of Sexey's School, Bruton, who died on April 11 at the age of eighty-two was known as a leading education. ist. From 908 for some years he was a member of the Somekse Education Committee ; during 1920-25 he parted on the first Burnham Committee ; in 1924 he ppctme president of the Incorporated Association of Headmasters; and in 1928 he was elected to represent the English secondary school headmasters at the Bucharest Conference. He was an honorary M.A. of the University of Bristol, honorary associate of University College, Reading, and a J.P. for Somerset.

The opening of Sexey's School in March 1891 was due indirectly to an Elizabethan, Hugh Sexey (or Saxey), the founder of Sexey's Hospital, Bruton, certain accumulated funds of this institution being appropriated for the purpose. The Right Hon. Henry Hobhouse was chairman of the school governors until 1930. Mr. W. A. Knight, a native of Castle Cary, was only twenty-four at the time of his appointment, and during the thirty-six years until his retirement in 1927 he developed a school with highly distinctive traits. Bearing in mind a fundamental idea of the promoters to impart a strong practical and scientific bias to the curriculum, the youthful headmaster became a pioneer in the development of science teaching in schools. General elementary science, natural history, chemistry, physics and botany all found a place in the curriculum. A generation or so later, the importance of biological science in schools received general recognition. Up to the present time numerous old Sexeians (many of whom are now well known in science) have taken a leading part in organising and developing biological work in schools, universities and research stations, both at home and overseas.

Gradually, under Mr. Knight's guiding hand, the school became known in the provincial universities, at the Universities of Oxford and Cambridge, and in Continental universities : so quick in its own soil was this acorn from a native Elizabethan oak. The record of Sexey's School shows that a proper emphasis on science in school teaching need not exalt material values at the expense of the spiritual. It is likewise re. markable that so many of Mr. Knight's pupils have developed strong literary and artistic tastes. The diverse fields in which alumni of this school have achieved distinction include the Church, literature, public affairs and administration.

In this little school, with her native human material and "Somerset's green lanes around her", the gifted headmaster was able to find full scope for his remarkable ability as a teacher, his organising genius and his inspiring ideals of attainment and character. Under Mr. Knight's tutelage one learnt as much out of school as within its walls. How, for example, could one remain indifferent to local history and topography when botany rambles with him led to such fascinating haunts as Wyke Champflower, Kingsettle Hill, Stourton Tower, Godminster and Holywater Copse ?

The perennial charm and stimulating force of Mr. Knight's personality had much to do with the success of Sexey's School. He took a vivid interest in his pupils and their doings, both at school and afterwards. His memory of anything concerning them was amazing. In an unsurpassed measure he earned and kept the esteem and strong affection of his pupils, to whom he was always a personal friend as much as the ideal headmaster. In the words of a versatile old pupil (R. W. Gregory), who achieved eminence as an electrical engineer :

You made us men, we boys of your own breed; And like the glowing steel, our mother wit

With cunning hand you hammered into shape,

And tempered for keen service to our kind.

You made our School; a thousand boys and more

You showed the way of life ; and thorough men,

Through all the continents of mother earth,

Hold you in honour.

JOHN READ

Present-Day educationists, if they had had the opportunity, would have studied with interest, and acclaimed many points in, the pedagogical approach and the school frganisation of Mr. Knight; for in many ways $j t$ was unique. For example, he would never allow 'holiday tasks', 'lines' or being kept in school gfter hours as a means of punishment. Both monitors (as they were then called) and staff could puysh by a system of exclusions-exclusion for a definite period (which varied with the crime) from the gymnasium, the museum, the reading room, the fives courts, and even from the class-room (out of school hours). So boys never ran the risk of their literary appreciation being undermined through having to write under duress interminable quotations from authors; they always enjoyed complete freedom during their holidays: but the 'exclusions' proved to be so inconvenient that any sensible culprit thought twice before repeating his offence.

The school year was also divided into four terms, so that half-term rests were not necessary, and fatigue was reduced.

Mr. Knight also seemed to have a genius for choosing his staff to the best advantage. He was not easily bemused by high academic honours; capacity for work and the full recognition of the value of esprit de corps played important parts when he made a choice. Mr. Knight himself recently told me that, other things being equal, he would not mind whether his assistant was a 'pass' or an 'honours' man. One of his assistants recently coined the expression "the Sexeian habit"- the habit for hard work.

As Prof. Read writes, his "memory of anything concerning [us] was amazing"; and whenever we met him afterwards (no matter how many years had elapsed between), he was the headmaster, we the boys. In 1947, when the school honoured me by inviting me to present the prizes on Speech Day (well-nigh a quarter of a century after I had left the school), he took my hand and, without so much as a 'how d'you do', said: "But you have changed; you were always so very thin". 
He was a great headmaster to whom science owes a considerable debt. He had no time for 'frills'; he got on with the job. The present headmaster, Mr. W. E. Page, writing to me recently, said: "We buried him, as he wished, with a minimum of ceremony and in the presence of scarcely a dozen people. It was moving in its stark simplicity." L. J. F. BRIMBLE

$$
\text { lds }
$$

Mr. JAMES HoRN. J Hornell February 24 at th ge of ighty-three, was a pioneer. He was one of tolfirst marine biologists and fishery naturalista de employed as such, and his experience of the fishefes of warmer seas placed him in a unique positio for many years. Educated in Scotland and at the University of Liverpool, his early experience was gained on a fisheries survey of the Channel Islands, where he met his wife. Shortly after this he left England, and in 1904 was appointed marine biologist to the Government of Ceylon and four years later in the same capacity to the Government of Madras. Here he began a connexion with tropical seas which occupied the greater part of his working life.

In those years his efforts were mainly directed to the practical application of his investigations, and his elucidation of the cause of a decline in the Ceylon pearl oyster fishery, recommending action which brought back a substantial measure of prosperity, is an outstanding example of his achievements in this direction. Later, he made many other attempts at fishery development, among which may be mentioned his plea for the culture of fish in ponds and lagoons. In urging work of this sort, he produced a report on the conditions under which fish are farmed or cultured at Arcachon and Commachio, recommending similar action in India. The time for what we recognize as developmental and operational research was not yet, however, and the will and resources to implement his schemes were not forthcoming in a way that was worthy of his proposals. In addition to the pres entation of development schemes and the day-to-day distractions of administration which became his lot when he was promoted to director of fisheries in 1918, he managed to do a considerable amount of descriptive biology. It is, indeed, a matter for remark that, living so far away from the academic contacts that might have helped him, he dealt with these studies so competently. There is no doubt that, had he remained in England, his contribution to more fundamental fishery research would have been out. standing.

A rather special aspect of his scientific outlook arose from the application of a fisheries ecology which included men and gear in relation to the fish they pursued. This led him to produce interesting descriptions of fishing boats and gear before he retired from the Madras Government service in the early 'twenties, and which culminated in his classic "Water Transport, its Origins and Early Development", published only two years before his death. After he left India, he made many visits to British Colonial Dependencies and Mandated Territories, from which emerged a series of short fishery surveys of great value. In 1934 he went to live in Hastings, which remained his home for the rest of his life. Here he entered into the scientific life of the town, studying and describing the structure of local fishing boats and giving his welcome assistance to the Sussex Sea Fisheries Committee.

Hornell was gifted with a power of lucid exposition, evident in all his many publications, making them both a pleasure to read and models of style to those who come after him and regret his passing.

R S. WTMPENNY

WE regret to announce the following deaths :

Sir Wyndham Dunstan, K.C.M.G., F.R.S., director during 1903-21 of the Imperial Institute, on April 20 , aged eighty seven.

Prof. F. S. Kipping, F.R.S., emeritus professor of chemistry in University College, Nottingham, on April 30 , aged eighty-five.

Dr. W. J. Perry, lately reader in anthropology in the University of London, on April 29, aged sixty-one

Sir Robert Robertson, K.B.E., F.R.S., formerly Government chemist, on April 28, aged eighty.

\section{$6 p$}

\section{Prof. Doris Mackinnon}

Prof. DoRIs L. Maceinnon, who retires from the chair of zoolggy a King's College, London, at the end of the pricent session, has held the post since 1927, whe sh fo succeeded Dr. Julian Huxley. She joined He/staff f King's in 1919 when the late Prof. A Dendy was head of the Department, and endeared 1. Aif to generations of students by her professional competence and her sympathetic, wise and helpful guidance. Prof. Mackinnon has published many noteworthy papers on her work, which deals almost entirely with parasitic Protozoa (especially flagellates and Sporozoa). During the First World War she joined the team of workers engaged in the diagnosis of amobic dysentery and intestinal protozoal infections for the War Office and Medical Research Committee (now Council). When she went to London after the War, she soon established a centre of research in protozoology-for years the only zoological (that is, non-medical) centre of the kind in Britain. By

\section{and VIEWS}

her teaching and research and the work of her pupils, she has thereby done much to advance the subject; and her publications include many solid and permanent contributions to protozoology. As too frequently in academic appointments, the responsibility of administration tends to make inroads on time for research ; but Prof. Mackinnon kept up a constant flow of publication and gave intercollegiate lectures of characteristic lucidity and thoroughness. In paying tribute to her gifts as a teacher, it would not be out of place to mention the admirable series of broadcast talks on natural history given to schools. Her services on the University and College Boards and Faculties were particularly appreciated, as she brought to them a breadth of outlook, sound judgment, scrupulous thoroughness and an altruistic approach not invariably observed on such bodies. Fortunately her retirement does not mean that she will cease her zoological work, and her colleagues and friends will still be able to enjoy her urbane and delightful companionship. 